\title{
間歇性外斜視の斜位化を目的とした視能訓練
}

\author{
松本富美子・大牟禮和代・富山 園子 \\ 谷田 清美・田野上恭子・大鳥 利文
}

近畿大学医学部 眼科学教室

\section{Orthoptic Training to Maintain Exophoria in Cases of Intermittent Exotropia}

\author{
Fumiko Matsumoto, Kazuyo Ohmure, Sonoko Tomiyama \\ Kiyomi Tanida, Kyoko Tanoue and Toshifumi Otori \\ Department of Ophthalmology, Kinki University School of Medicine
}

要 約

間歇性外斜視の症例に対し，斜位化を目的とした視能訓練を行なった。症例は 5 例で，年齢は 8

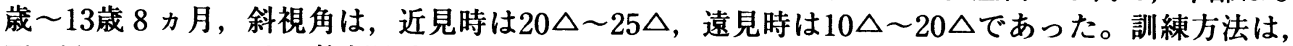
Flashing methodによる抑制除去訓練, Framing cardによる生理的複視認知訓練, Stereo cardやフ リズムによる融像訓練を順次行なった。抑制除去訓練は院内で, 他の訓練は主に家庭で 1 日 $2 \sim 3$ 回, 1 回 5〜10分程度行ない, 全訓練期間は平均14.6週間であった。結果, 訓練前は間歇性外斜視 であった 5 例全例が, 訓練後には㧕制が除去され融像力が強くなり, 各むき眼位や各距離で安定し た外斜位になった。間歇性外斜視に対する視能訓練は有用で，特に抑制除去訓練を行なうことが斜 位化するために有効であると考えた。

\begin{abstract}
We performed two types of orthoptic trainings in 5 cases of intermittent exotropia in order to maintain exophoria and clear single binocular vision. Their ages were between 8 and 13.8 years and they had exodeviation of between 20 and $25 \Delta$ at near fixation and exodeviation of between 10 and $20 \triangle$ at distance fixation. Our training schedule was initiated by anti-suppression training using a trained at home by a framing card to make them conscious of physiological diplopia. Finally, fusion training using a stereo card and a single prism was performed. Each training was done for 5 to 10 minutes twice or three times a day. The mean training period was about 14.6 weeks. After the training, all of 5 cases had stable exophoria and clear single binocular vision at all positions of their gaze and at both near fixation and distance fixation. Suppression was effectively eliminated and their ability of fusional convergence was improved. The present results seem to demonstrate that orthoptic trainings are useful in the treatment of intermittent exotropia. We speculated that antisuppression training might be most useful and effective in a series of the trainings.
\end{abstract}

連絡先（テ589）大阪府大阪狭山市大野東377-2

近畿大学医学部付属病院 眼科 松 本 富美子

Tel. $0723-66-0221$

Key words : orthoptic training, intermittent exotropia, physiological diplopia, suppression, anti-suppression training 


\section{I. 緒 言}

間歇性外斜視は通常両眼視機能は良好とされ るが，外斜視時に抑制が存在し，近見立体視機 能は有するが斜位時にも生理的複視の抑制が報

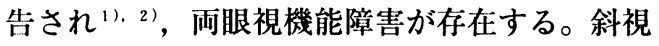
手術を行なっても眼位の戻りや, 再び間歇性外 斜視の出現をみることが問題となる。間歇性で あっても, 徐々に斜視の頻度が多くなってきた り悪化してくる症例も経験する。今回われわれ は, 間歇性外斜視の症例に対し, 両眼視機能や 斜視角の維持, 眼位の改善を促すために斜位化 を目的とした視機能訓練を行ない有効な結果を 得たので報告する。

\section{II. 対象と方法}

対象は, 平成 7 年 5 月〜 8 月までに当科弱視 斜視外来を受診した間歇性外斜視症例の中で, 8 歳以上で理解力があること, 斜視角は $20 \triangle$ 以 下であること, 立体視機能があること, 弱視の 既往がないこと, 通院できることなど視能訓練 の適応となる間歇性外斜視 5 例とした。主訴は 全例眼位異常であり, うち 1 例は眼精疲労や複 視を伴っていた。斜視手術を行なった症例は含 んでいない。年齢は, 8 歳 0 力月〜 13 歳 8 力月 までであった。

判定のための検査は, 眼位検査, 輻湊近点, 融像幅の測定を行なった。眼位検査は, 交代プ リズムカバーテスト（以下APCTとする）によ る定量時に, 調節視標を固視したときの斜視〜 斜位のコントロール状態も観察した。また Bagolini Red Filter Barを片眼に負荷し，斜位 が外斜視になるフィルターの濃度（No.）も融像 力の強さの一基準とした。輻湊近点は, 調節視 標と片眼に赤フィルターを負荷したペンライト の光視標の 2 種類の視標を用いて輻湊限界点を 測定し, 生理的複視の有無も確認した。輻湊側 の融像幅は, プリズムバーを両眼の前に置き 0.6 の単独ランドルト環の調節視標を用いてblur point, break point, recovery pointを测定し た。立体視検査にはTNOステレオテストを使用 した。

訓練の方法は，図 1 に示したように金谷らの

\section{訓練方法}

\section{1. 抑制除去訓練}

Flashing method

2. 生理的複視訓練

Two pencils

Framing card

3. 輻湊訓練

光視標十赤フィルター

Convergence card

4. 融像訓練

\section{Stereo card \\ Prism base out}

図 1 . 訓練方法

方法3)，4，5)を参考に症例に応じて抑制除去訓 練, 生理的複視認知訓練, 融像訓練を行なった。 抑制除去訓練としてはFlashing methodを院内 で行なった。Flashing methodは図 2 a に示し たように，固視眼に赤フィルターを装用し光視 標を固視させcover-uncoverを繰り返して行な い，斜視眼の道ずれ領に遮蔽と光刺激を交互に 与え抑制を除去していく方法である。Flashing methodの刺激条件については，非日常的な刺激 から日常的な刺激へと刺激条件を変えて以下の ように設定した。具体的には部屋は，抑制が染 い場合ほど暗室で，抑制が浅くなれば明室で行 なった。視標は，抑制が深いときにはペンライ 卜視標を用い，浅くなれば調節視標へと順次変 えて訓練を進めた。視標の位置は，患児の抑制 の状態に合わせ抑制が浅い距離，抑制が浅いむ き眼位から行なった。Flashing methodを行な う刺激時間は, 1 回30分〜60分であった。図 2 b に示したような他の訓練は, 院内での指導の 後主に家庭で 1 日 $2 \sim 3$ 回, 1 回 $5 \sim 10$ 分程度 行なった。訓練効果の判定は 2 週間毎に来院さ せて先述の検査で評価し, 次の家庭訓練の方法 を患児に充分説明し母親の監視のもとに実行さ 


\section{Flashing method}

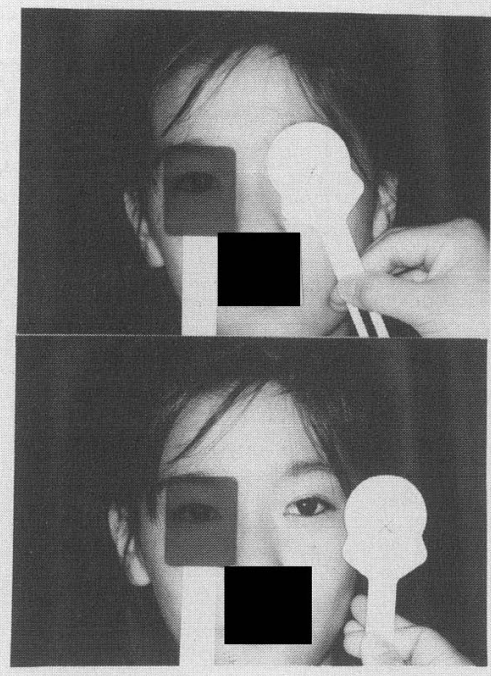

図 2 a. Flashing methodによる抑制除去訓練 固視眼に赤フィルターを装用し, 斜視眼に カバーとアンカバーを絽り返して行なう。

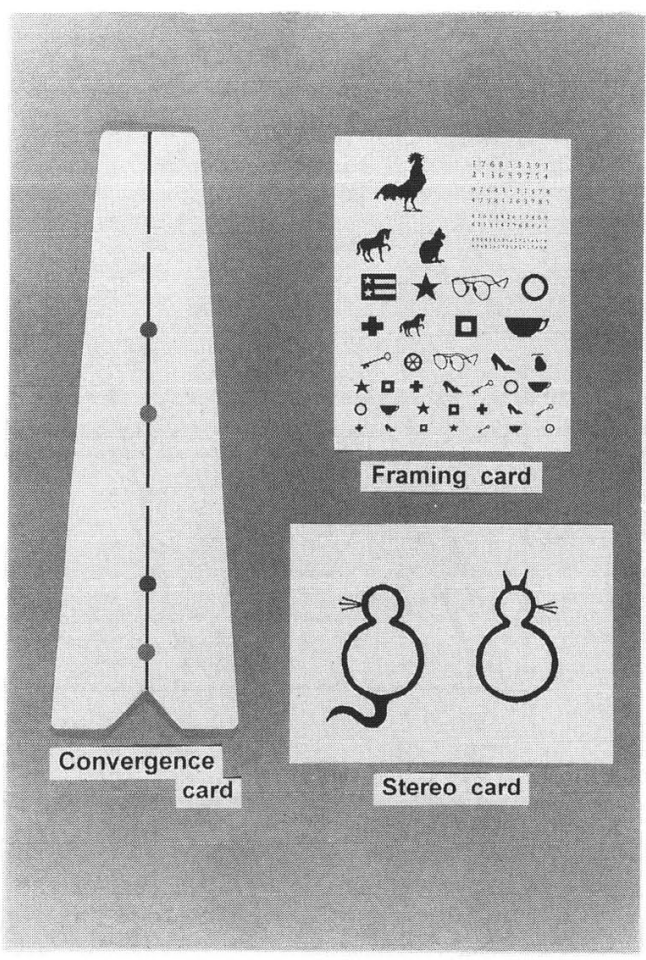

図 2 b. 家庭訓練用具
せた。

訓練の目標は，(1)間歇性外斜視の斜位化，(2) 外斜視時に交叉性複視を感じること, (3)融像性 輻湊幅は斜視角の $2 \sim 3$ 倍獲得することとし, 眼精痩労や近視化の副作用がでないよう充分注 意しながら行なった。

\section{III. 結 果}

訓練前の斜視角は, APCTで近見時は $20 \triangle$

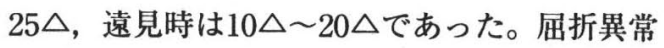
は, $\mathrm{S}+0.75 \mathrm{D} \sim \mathrm{S}-2.5 \mathrm{D}$ までで, 矯正視力は 1.0 以上であった。訓練前は間歇性外斜視であっ た 5 例全例が, 訓練後には抑制が除去され融像 力が強くなり, 各むき眼位や各距離で安定した 外斜位になった。全訓練期間は, 9 週間〜 27 週 間で平均14.6週間であった。

\section{1. 眼位のコントロールについて（図 3 a, b)}

近見時の眼位は, 訓練前斜視であった者 1 例, 斜位〜斜視 3 例, 斜位 1 例であったが, 訓練開 始後 $3 \sim 5$ 週間で全例が斜位化した。遠見時の 眼位は訓練前斜視であった者 2 例, 斜位一斜視 2 例，斜位 1 例であったが, $4 \sim 7$ 週間で全例 が斜位化した。どの距離でも訓練後は斜位が維 持できている。また斜位の強さを，Bagolini Red Filter Barを負荷し, 斜位が破れるフィル ターの濃度で測定した。訓練後には，片眼に Bagolini Red Filter BarのNo. 14 (遮光率約78\%) で斜位が破れた症例が 1 例, 他の 4 例はNo. 17 （遮光率約 $97 \%$ ）を負荷しても斜位が維持できる ようになった。

\section{2. 輻湊近点の結果（図 4 a, b )}

訓練前の輻湊近点は, 調節視標では 5 例中 2 例，赤フィルターを負荷した光視標では 5 例中 4 例が輻湊不全を示したが, 訓練後には全例が 正常值以内に改善し, 6 力月後も維持できてい る。また生理的複視は, 調節視標では 5 例中 2 例に抑制があり，赤フィルターを負荷した光視 標でも 5 例中 1 例に抑制があった。また症例 2 は二重対応であったが, 訓練後は全例が正常な 生理的複視を自覚するようになった。

\section{3.プリズム輻湊幅の結果（図 5 ）}

訓練前のプリズム輻湊幅は, 近見時, 遠見時 共に測定できたのは症例 4 の 1 例のみで, 他の 


\begin{tabular}{|c|c|c|c|c|}
\hline 症 例 & 訓練前 & 斜位化(䓢) & 訓練後 & 6r月後 \\
\hline 1 T.K & $\bigcirc$ & 4 & $\bigcirc$ & $\bigcirc$ \\
2 T.F & $\bigcirc$ & 7 & $\bigcirc$ & $\bigcirc$ \\
3 S.N & $\bigcirc$ & 5 & $\bigcirc$ & $\bigcirc$ \\
4 S.O & $D$ & 6 & $\bigcirc$ & $\bigcirc$ \\
5 H.H & $\bigcirc$ & 0 & $\bigcirc$ & $\bigcirc$ \\
\hline
\end{tabular}

図 $3 \mathrm{a}$. 眼位のコントロール状態

\begin{tabular}{|c|c|c|c|c|}
\hline 症例 & 訓練前 & 斜位化(週) & 訓練後 & 6ヶ月後 \\
\hline 1 T.K & $\bigcirc$ & 3 & $\bigcirc$ & $\bigcirc$ \\
2 T.F & $\bigcirc$ & 5 & $\bigcirc$ & $\bigcirc$ \\
3 S.N & $\bigcirc$ & 0 & $\bigcirc$ & $\bigcirc$ \\
4 S.O & O & 4 & $\bigcirc$ & $\bigcirc$ \\
5 H.H & O & 2 & $\bigcirc$ & $\bigcirc$ \\
\hline
\end{tabular}

図 $3 \mathrm{~b}$

$\mathrm{a}$ には遠見時，bには近見時を示す。

$\bigcirc$ : 斜位, 1 : 斜位 $\sim$ 視,

斜位化とは，外斜位を維持できるようになったことを意味し，期間を週で表した。

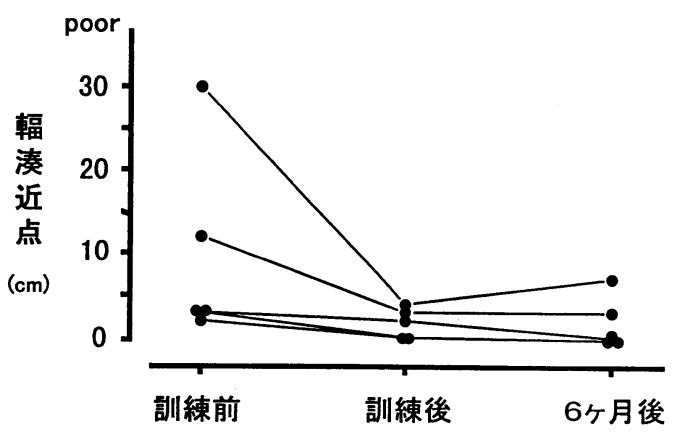

図 $4 \mathrm{a}$. 輻湊近点

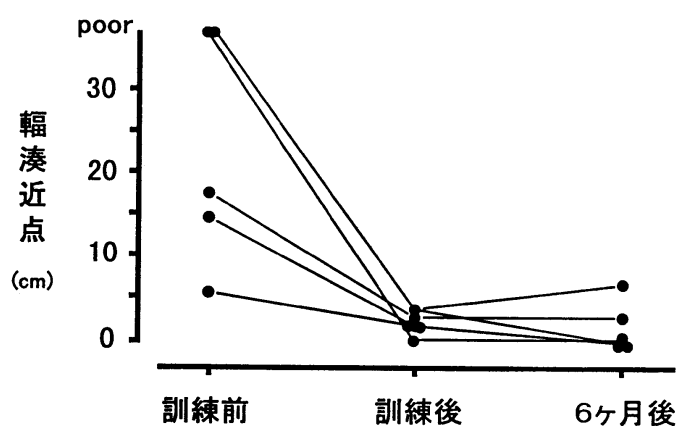

図 4 b

a には調節視標， b には赤フィルターを負荷した光視標での輻湊近点を示す。

症例はプリズムバーを眼前に置くと外斜視とな ってしまったり，斜位であっても抑制があるた めに輻湊幅の限界が自覚できず測定不能であっ た。訓練後の輻湊幅は, 近見で50 80 $\triangle$, 遠見 で55〜80 $\Delta$ と全例が改善した。 6 カ月後には訓 練終了時の輻湊幅より低下した症例もあったが, 斜視角の 2 倍量より低下している症例は, 症例 5 の近見時のみである。症例 5 は眼位のコント ロールに悪化はなく，外斜位を維持しているの で経過観察中である。

\section{4. 代表症例 2 例の経過（図 6, 図 7)}

代表症例 1 を図 6 に示した。症例 1 は 11 荗の 男子, 訓練前の視力は, $\mathrm{R} \mathrm{V}=1.2 \mathrm{p} \quad(1.2 \mathrm{p} \times$ $\mathrm{S}+0.5 \mathrm{D}), \quad \mathrm{LV}=1.2 \mathrm{p} \quad(1.2 \mathrm{p} \times \mathrm{S}+0.5 \mathrm{D})$ で
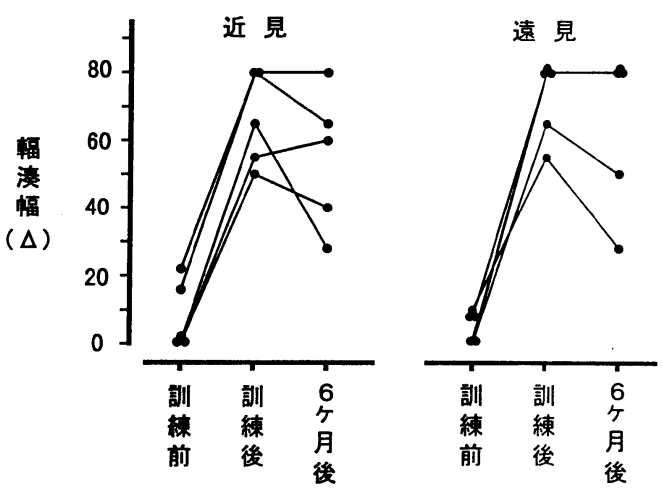

図 5 . 輻湊幅

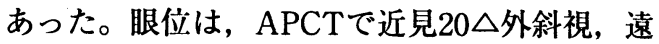
見14 $\triangle$ 外斜視で, 近見の下方視時のみ外斜位と 


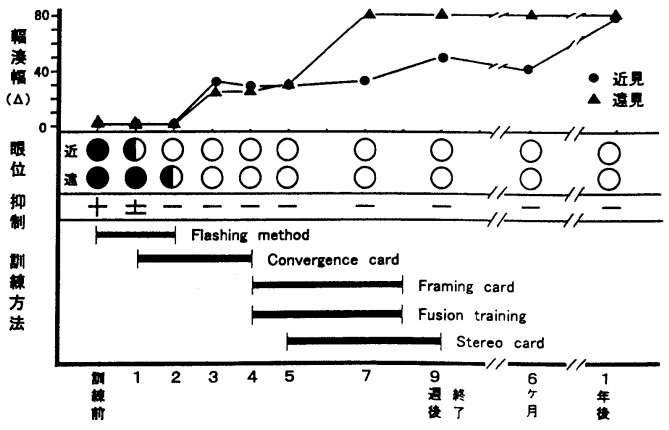

図 6. 症例 1 の経過

眼位の項の○は外斜視，○は外斜位〜外斜視， ○は外斜位の状態であることを示す。

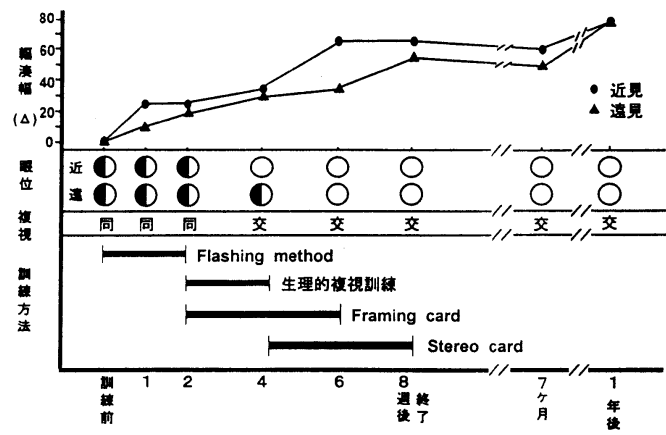

図 7 . 症例 2 の経過

複視の項の「同」は同側性複視，「交」は交叉 性複視を認識したことを示す。

なった。両眼の下斜筋過動症を伴い V 型外斜視 の傾向があった。輻湊近点は延長しており, 生 理的複視は抑制されていた。近見立体視機能は, TNOステレオテストでは下方視で240" であっ た。

視能訓練は, 外斜視時の抑制や生理的複視の 抑制に対し, Flashing methodによる抑制除去 訓練を行なった。院内での約30分間の訓練と家 庭で 1 日 2 回, 1 回 3 分間の訓練を指導した。 訓練 1 週間後には生理的複視が認識でき，また 外斜視時に光視標であれば時々交叉性複視を認 識できるようになった。眼位は，抑制が除去さ れるとともに外斜位にコントロールできるよう になり， 2 週間後にはプリズム輻湊幅も改善し た。 4 週間後には, 眼位は第 1 眼位では近見で も遠見でも外斜位となったが，上方視で外斜視
が残存したため, 融像力を增強するために Stereo cardでの家庭訓練を指導した。9 週間後 には全ての距離や様々なむき眼位でも外斜位と なり，プリズム輻湊幅も著明に改善した。斜位 は, Bagolini Red Filter BarのNo. 17を負荷し ても維持できるようになったため訓練を終了し た。眼精疲労や近視化の副作用はおこらなかっ た。訓練終了 1 年後でも斜位は維持できている。

代表症例 2 を図 7 に示した。症例 2 は13歳の 男子で, 訓練前の視力は, $\mathrm{R} \mathrm{V}=(1.0 \times \mathrm{S}-0.5$ $\left.\mathrm{D}: \mathrm{C}-0.25 \mathrm{DAX} 100^{\circ}\right), \mathrm{L} \mathrm{V}=(1.0 \times \mathrm{S}-$ $2.25 \mathrm{D}: \mathrm{C}-0.5 \mathrm{DAX} 80^{\circ}$ ) で，平成 4 年より眼 鏡は常用している。眼位はAPCTで近見 $25 \triangle$ 外 斜位，遠見 $25 \triangle$ 外斜視であった。輻湊近点は, 赤フィルターを負荷した光視標でも $4 \mathrm{~cm}$ と近点 距離は正常值以内であるが, 輻湊近点が破れた 時の複視が同側性であり, 両眼視機能は二重対 応と考えた。立体視機能は，TNOステレオテス トで60"であった。

Flashing methodによる抑制除去訓練を，院 内で 1 回約60分間を 3 回行ない交叉性複視を認 識できるようになり正常対応となった。その後 症例 1 と同様に融像訓練を行ない, 7 週間後に はBagolini Red Filter BarのNo. 17を負荷して も外斜位が維持できるようになり，9 週間後に 訓練を終了した。訓練終了 1 年後でも外斜位は 維持できている。

\section{IV. 考按}

間歇性外斜視の症例は，一般に両眼視機能は 良いとされているが，斜視時における抑制につ

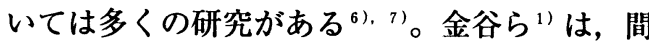
歇性外斜視の症例は斜位時にも生理的複視の抑 制があり，正常人では生理的複視の抑制はなか ったと報告している。今回の我々の結果からも， 間歇性外斜視症例の外斜視時，外斜位時ともに 抑制が存在することがわかった。

輻湊を中心とした視能訓練は，様々な施設で

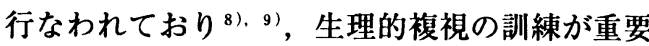
とされている ${ }^{10)}$ 。当科でも以前より間歇性外斜 視に対して輻湊訓練を行なってきたが"1)，輻湊 近点は著明に改善されるものの，外斜位の維持 については, 生理的複視の訓練を行なったにも 
関わらず効果が不十分である症例を経験した。 Pritchard $^{2)}$ は, 間歇性外斜視の生理的複視の抑 制野を測定し斜視角と抑制野との関係を示し, 症例によって道ずれ領から広がる様々な抑制野 を示している。以前, 当科で訓練効果の悪かっ た症例では, 各症例の抑制野と, 生理的複視認 知訓練で刺激を行った網膜領域との設定が悪か ったためではないかと考える。

生理的複視を認識するためには, 正常なホロ プターの形成が必要である。両眼の中心窩で 1 つの視標を固視し, 眼位は正位か斜位でなくて はならない。また生理的複視を認識するために は, 両眼の中心裔で固視するための視標と, 生 理的複視を感じるためのもう 1 つの視標との 2 視標間の距離が問題となる。正常人では, どの 距離に視標を置いても生理的複視は認識できる が, 抑制のある症例では, 生理的複視を認識す る距離と認識しない距離がある。つまり生理的 複視を認識するための 2 視標間の距離の設定は, 各症例の網膜の抑制野にあった刺激領域に置く ことが必要なのである。この 2 視標間の距離は, たとえば $15 \mathrm{~cm}$ と $30 \mathrm{~cm}$ で約 $9 \triangle, 10 \mathrm{~cm}$ と $5 \mathrm{~m}$ で

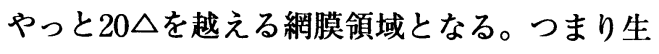
理的複視認知訓練では, 各症例の抑制野にあわ せて視標間距離を変化させることが最も重要で あると考える。

今回, 抑制除去訓練を行なうと, 融像訓練を 開始する前から輻湊側融像幅が改善し, 眼位が 斜位化してきた。間歇性外斜視症例の眼位のコ ントロールと抑制については金谷らも指摘して いるが4), 我々の結果からも推測された。また 抑制野あるいは抑制の深さと眼位のコントロー ルとの関係において, 訓練経過中に非常に興味 ある傾向があった。Flashing methodで抑制除 去訓練を行なっていくと, まず生理的複視の認 識が可能となり，眼位は斜位が多くなってきた。 外斜視時の交叉性複視よりも, 生理的複視の方 が先に認識できるようになったことは，中心㸗 付近の抑制の方が道ずれ領付近の抑制よりも抑 制が浅いことが推測される。また生理的複視の 認識ができると斜位化しはじめたということは, 中心窝に近いある一定の網膜領域に抑制がなけ れば，間歇性外斜視が外斜位になることができ
るのではないかと考える。訓練を続行すると， 外斜視時の交叉性複視が認識できるようになり, このころより完全に外斜位となった。外斜位を 維持するためには，おそらく道ずれ領に近い網 膜領域に抑制がないことが必要ではないかと考 えた。これらの結果から，間歇性外斜視の眼位 を完全に斜位化させるためには，全網膜の抑制 野を除去することが重要であると考える。

Flashing methodの抑制除去訓練方法は, カ バーテスターと赤フィルター, ペンライトと簡 単な器具で行なうことができる。当科では Flashing methodの訓練を行なう以前には, 抑 制を完全に除去できずに訓練効果が充分でない 症例があり，斜位化することが困難であった。 訓練効果を確実にあげるためには，抑制のある 症例では訓練の初期段階にFlashing methodを 行なうことが重要である。斜視角が大きく，斜 視手術の対象となる症例でも, 術前に抑制除去 訓練を行なうことにより，眼位のもどりにも多 少好影響を及ほし，たとえ眼位の戻りがあって も斜位を維持できている。

間歇性外斜視の症例に対する視能訓練は, 抑 制を除去することが重要であるが, 訓練対象と なる年齢が高く低年齢では困難である。最近で は間歇性外斜視でも健診や啓蒙から受診年龄が 低くなってきた。抑制除去の一方法として交代 遮蔽法があり低年齢でも実施可能であるが, 精 神的な苦痛など様々な問題点もある。今後眼位 や両眼視機能が悪化する前に予防的にも施行で きる訓練方法を考按したい。

\section{V. 結 論}

間歇性外斜視 5 例に対し視能訓練を行なった 結果, 訓練前は間歇性外斜視であった 5 例全例 が, 訓練後には各むき眼位や各距離で安定した 外斜位になった。間歇性外斜視の眼位は, 抑制 を除去すると斜位となり融像力を強化すると斜 位が安定した。間歇性外斜視の眼位のコントロ 一ルは，両眼視機能に支配される因子が大きい と考えられ，間歇性外斜視に対して斜位化を目 的とする視能訓練は有効であると考えた。

稿を終えるにあたり，ご教授いただきました 
金谷まり子先生，ご校閱いただきました楠部亨 先生，ご協力いただきました（株）トプコン本 間氏，北島氏に心より感謝いたします。

\section{文献}

1）金谷まり子他：間歇性外斜視における生理的 複視の抑制．眼臨82：343-350, 1988.

2 ) Pritchard, C.: Suppression of Physiologic Diplopia in Intermittent Exotropia. Am. Orthopt. J., $31: 72-79,1981$.

3 ）金谷まり子他：駿河台日大病院における融像 訓練一輻湊を中心としてーその 1 ．検查と訓 練法法. 眼臨81：1271-1276， 1987.

4 ）金谷まり子他：駿河台日大病院における融像 訓練一輻湊を中心としてーその 2 . 結果. 眼 臨82:343-350, 1988.

5 ) Luke, N. E.: Antisuppression techniques in exodeviations. Am. Orthopt. J., 15: 42-47, 1965.

6 ) Pratt-Johnson, J. et al: Suppression Associated with Exotropia. Canad. J. Ophathal., $4: 136$ 144, 1969

7 ）栗屋忍他：斜視の抑制暗点をめぐる問題点. 眼科 $181 ： 285-294,1976$.

8 ）井上浩彦他：輻湊練習法. 眼科 $9 ： 124-130$, 1967.

9）門脇文子他：筋性眼精疲労の視能訓練一とく に代償不全外斜位について - 日本視能訓練 士協会誌 $14: 89-92,1986$.

10）渋谷政子他：眼精疲労に対する輻湊融像訓練 の効果. 日本視能訓練士協会誌 $24: 51-57$, 1996.

11）石田麗子他：輻湊不全を伴う間歇性外斜視に 対する輻湊訓練の有用性. 日本視能訓練士協 会誌18：168-172， 1990.
1. 抑制が完全にとれるまではできるだけ頻回に 来院してもらい, 主に病院で訓練していった 方がよいのではないかと思うのですが，いか がでしょうか。

2. 訓練終了の基準，その後のフォローについて 教えて頂きたいと思います。

\section{答弁}

1. 当科でも flashing methodは院内で集中的に行 う症例が多いです。その方が効果が早く確実 だと思います。

2. 訓練終了の基準は，斜視にした時，抑制がな いこと，どのむき眼位，距離でも斜位である こと，輻湊幅が眼位の 3 倍量あること， Bagolini Red Filter Barを負荷して, 斜位が 斜視に破れるフィルターNo.が最低14より濃い こととし，1，3，6 カ月後， 1 年後に来院 させてチェックしています。

質問 (帝京大学 且井 千恵)

1. 5 症例の治療前の網膜対応はいかがでしたか。

2. 症例 1 は, 治療前に下方視のみTNO $(+)$ と ありましたが, convergenceの能力からみて 正面視においても立体視は可能のように思わ れましたが，その点はいかがでしたか。

\section{答弁}

1. 症例 2 は, 二重対応間歇性外斜視でしたが, flashing methodで正常対応化し，交叉性複視 （NRC）となり，斜位化も他の症例と同じく できました。

2. 症例 1 は, $\mathrm{V}$ 型傾向の外斜視で，下方で比較 的安定した斜位がありましたが，第一眼位で は時には斜位になる程度の状態でした。訓練 後には安定した斜位になりました。 